\title{
Clinical features and outcomes in chronic myeloid leukemia with T315I mutation
}

\author{
Julia Yu. Vlasova ${ }^{1}$, Elena V. Morozova ${ }^{1}$, Oleg A. Shukhov ${ }^{2}$, Maria V. Barabanshchikova ${ }^{1}$, Tatiana L. Gindina ${ }^{1}$, \\ Ildar M. Barhatov ${ }^{1}$, Irina S. Martynkevich ${ }^{3}$, Vasily A. Shuvaev ${ }^{3}$, Anna G. Turkina ${ }^{2}$, Boris V. Afanasyev ${ }^{1}$ \\ ${ }^{1}$ R. M. Gorbacheva Institute of Children Oncology, Hematology and Transplantation, department of Hematology, Transfusiology \\ and Transplantation, I. P. Pavlov First St. Petersburg I. Pavlov State Medical University, St. Petersburg \\ ${ }^{2}$ National Medical Research Center for Hematology, Russian Ministry of Health, Moscow, Russia \\ ${ }^{3}$ Russian Research Institute of Hematology and Transfusiology, St. Petersburg, Russia
}

Dr. Julia Yu. Vlasova, R. Gorbacheva Institute of Children Oncology, Hematology and Transplantation, First St. Petersburg I. Pavlov State Medical University, L. Tolstoy St. 6-8, 197089, St. Petersburg, Russia

\section{Summary}

Resistance to tyrosine kinase inhibitors (TKI) in patients with chronic myeloid leukemia (CML) is frequently caused by point mutations in the $B C R-A B L$ kinase domain, including the gatekeeper mutant T315I, which confers a high degree of resistance to all currently approved tyrosine kinase inhibitors, except of ponatinib. The aim of our study was to evaluate the results of different treatment modalities in CML patients with T315I mutation.

\section{MATERIALS AND METHODS}

Retrospective analysis of $53 B C R-A B L^{\mathrm{T} 315 \mathrm{I}}$-positive CML patients (pts) was done. Allogeneic bone marrow transplantation (allo-HSCT) was made in 16 pts, 37 pts received only pharmacological therapy (21 pts received TKI as monotherapy or in combination with other drugs other 16 pts received hydroxyurea, interferon- $a$ or chemotherapy). At the time of T315I detection 29 (55\%) pts were in CP, 19 (36\%) pts had AP and $5(9 \%)$ pts were in BC. Median (Me) age at the time of mutation detected was 47 years (15-76) (38 years in HSCT-group). In allo-HSCT group 11 (69\%) pts had unrelated donors, 11 (69\%) pts received more than 2 lines TKIs before HSCT, 2 (12\%) pts were in BC at the time of HSCT, 5 pts were in AP, 7 pts were in $\mathrm{CP} \geq 2$. The number of points on EBMT scale: 3-4 points $12(75 \%)$ pts, $5-7$ points $-4(25 \%)$ pts. Conditioning regimen in $13(81 \%)$ pts had reduced intensity. Me time to HSCT after T315I detection was 10 months (1-38). Mutation analysis was performed by Sanger sequencing. Overall survival (OS) was estimated by Kaplan-Meier method with log-rank test for comparison between groups. Cox regression was used for multivariate sur-
Phone: +79650415505

E-mail: jj_vlasova@mail.ru

vival analysis that included next covariates: age, phase on the time of mutation detection, performance of allo-HSCT, time from TKI treatment initiation to T315I detection.

\section{RESULTS}

The mean follow-up time after T315I detection was 21 months (1-100). 5-years OS in whole group was $42 \%$. According to multivariate analysis only CML phase at the time of mutation detection significantly affect to survival in whole group. All patients in $\mathrm{BC}(\mathrm{n}=5,2$ in HSCT group and 3 in non-HSCT group) died within first year after T315I indication wherein Me survival time was 1.3 month. 5-years OS in non-HSCT group $(n=37)$ was $42 \%$ with Me survival time 2.8 years. 5 -years OS after allo-HSCT $(n=16)$ was $37 \%$ with Me survival time 5 months. All living patients after allo-HSCT are in deep molecular response. There was no significant difference in 5-years OS between TKI $(n=21)$ and non-TKI $(n=16)$ pharmacological therapy (non-HSCT) groups (42\% and $47 \%$ respectively, $\mathrm{p}=0.53$ ).

\section{CONCLUSION}

Detection of T315I mutation in TKI-resistant patients is extremely unfavorable factor for survival, especially in the advanced phase CML, and it is a great reason for switching to ponatinib or other new potential investigated drugs if possible. Allo-HSCT can be a potential option for this group of patients in case of good selection, however, taking transplant risks into consideration.

\section{Keywords}

Chronic myeloid leukemia, T315I mutation, allogeneic transplantation of hematopoietic cells, drug resistance. 


\section{Introduction}

Over last decade, a fundamentally new treatment approach has been developed for chronic myeloid leukemia (CML) patients based on tyrosine kinase inhibition (TKI) concept. I.e., imatinib proved to be a targeted drug which acts directly on the chimeric BCR-ABL protein, thus interfering intracellular signaling cascade leading to abnormal cell growth in CML [9]. The TKI therapy allowed sufficient life prolongation of CML patients, decreased progression rates and improved quality of life $[9,15,16,28,32,38]$. The $2^{\text {nd }}$ generation of the TKI's (dasatinib, nilotinib, and bosutinib) have shown their efficiency in case of Imatinib resistance or intolerance.

Despite such impressive results, around one-quarter of the patients do not achieve optimal response to imatinib, or loose therapeutic effect with time. CML resistance to imatinib is more common at advanced disease stages, rather than in chronic phase (CP) [9].

Insufficient response to imatinib treatment may caused by two mechanisms, i.e., BCR-ABL-dependent, or BCR-ABL-independent. The latter include, e.g., additional chromosomal aberrations, activation of BCR-ABL-independent signal pathways, excessive imatinib binding to blood transport proteins, or increased expression of MDR proteins [17]. Among BCR-ABL-dependent resistance, $B C R-A B L$ mutations, as well as additional copies of the $B C R-A B L$ chimeric gene should be mentioned $[11,19]$.

Point mutations of the $B C R-A B L$ kinase domain are revealed in $30-45 \%$ of resistant patients, thus being a prevailing factor of imatinib therapy failure, more often detectable in patients with secondary resistance, and at the advanced stages of disease [14, 18, 24, 35]. Emergence of point mutations is connected with increased kinase activity of the BCR-ABL protein. New $B C R-A B L$ mutations occur on basis of genomic instability determined by different mechanisms, e.g., effects of reactive oxygen species which induce oxidative stress to genetic material [33]. Among the $B C R-A B L$ kinase domain (KD) mutations, the T315I mutation should be especially mentioned since it causes insensitivity of leukemic cells to both imatinib and $2^{\text {nd }}$ generation of TKIs (TKI2) $[35,3,30$, $33,34,37]$

A treonine-to-isoleucine substitution at the position 315 of the functional kinase domain disturbs spatial binding of the functional ABL domain, thus causing loss of TKI-binding hydrogen bonds. Except of spatial obstacles, the T315I mutation is associated with lacking self-inhibitory regulatory mechanisms. This mutation is the only marker causing full resistance to imatinib, as well as other second-generation TKIs (nilotinib, dasatinib, bosutinib). This mutation is found at a rate of 12 to $20 \%$ among all $\mathrm{KD}$ mutations of $B C R-A B L$ gene.

It is shown that the disease prognosis in T315I-positive CML is sufficiently worse than in cases with optimal response to TKI therapy. As shown by various authors, the overall survival (OS) and progression-free survival (PFS) among patients with T315I mutation is lower than in patients with optimal response to TKI, or patients with resistance to TKI in case of absence of T315I mutation [25]. The CML patients with T315I mutation have the median of PFS only 11.5 months and median for OS as 22.4 months since mutation emergence [26]. Bad prognosis and resistance to TKIs in such cases boosted development of novel drugs. Ponatinib is the only known TKI which showed clinical efficiency in T315I-positive CML patients. So far, however, this drug is not registered in Russian Federation.

Allogeneic transplantation of hematopoietic stem cells (allo-HSCT) is a real, available and recommended choice for the patients with T315I. There are several studies showing allo-HSCT efficiency in these patients. Velev et al. have reported some results of allo-HSCT from matched unrelated donors, or umbilical blood cells to $8 \mathrm{CML}$ patients with T315I mutation. Five patients are alive, including three cases of complete molecular response (CMR), one, with complete cytogenetic response (CGR), and one, with hematological level of response (HR), with the median of observation time as 13 months[39].

According to Nicolini et al., a two-year OS in 64 patients with T315I mutation after allo-HSCT proved to be 59\%, $67 \%, 30 \%$ и $25 \%$, respectively, for chronic phase, acceleration phase (AP), blast crisis (BK), and $\mathrm{Ph}+$ acute lymphoblastic leukemia in the allo-HSCT group., respectively, with the median observation time as 26 months. Most transplants were performed from fully matched unrelated donors and fully matched related donors [23].

The same group has published combined data from the Phase II PACE study and EBMT Register comparing ponatinib and allo-HSCT results. A total of $184 \mathrm{CML}$ and Ph+ ALL patients with T315I mutation, at $>18$ years and older at any phase of disease, were included into the study. OS rates were sufficiently higher in the patients in CP receiving ponatinib, similar in AP for the both groups, and sufficiently increased in the patients with $\mathrm{Ph}+\mathrm{BC}$ [22].

A group of Chinese workers has published data on 22 allo-HSCTs, most of them $(n=16)$ were performed from haploidentical related donors. The two-year relapse-free survival after allo-HSCT comprised $80 \%, 73 \%$, an $0 \%$, respectively, for $\mathrm{CP}, \mathrm{AP}$, and BC phase. The median time of follow-up was 17.3 months, 14 patients survived, including 13 with complete molecular response and 1 with extramedullary relapse. Hence, allo-HSCT from haploidentical related donor seems to be a therapeutic option for CML patients harboring T315I mutation. Generally, allo-HSCT from either type of transplant may provide long-term survival, without signs of minimal residual disease [41].

Moreover, in view of sufficient number of high-risk relapse CML patients, a role of early posttransplant TKI prophylaxis is considered. A number of appropriate studies was performed, including those of TKI2. For instance, Zeidner et al., using post-transplant TKI to prevent relapse have shown higher cumulative CMR rates and lower incidence of mortality [42]. Interestingly, TKI application is associated with lower incidence of extended chronic GVHD, probably, due to influence of TKI on platelet-derived growth factor receptor. 
Optimal dosage of TKI's and duration of treatment are also under studies [1].

In case of inability to perform allo-HSCT, one may use Interferon- $\alpha$ (IFN) since its efficiency is shown in patients with $B C R-A B L^{\mathrm{T} 315 \mathrm{I}}$ as well [8]. Major molecular response (MMR), and even CMR were registered in some patients with this mutation treated by means of combined therapy with TKI and IFN $[4,12,13]$.

Hence, the aim of present study was to evaluate our results concerning different treatment modalities in CML patients with T315I mutation of $B C R-A B L$ oncogene.

\section{Patients and methods}

A retrospective study was performed for $53 \mathrm{CML}$ clinical cases with detectable T315I mutation in $B C R-A B L$ gene. Sixteen patients underwent allo-HSCT (repeated allo-HSCT was carried out in two cases). Thirty seven patients received only pharmacological therapy. To perform the study, we analyzed medical histories and outpatient cards of $16 \mathrm{CML}$ patients who underwent allo-HSCT at the clinics of the R. Gorbacheva Memorial Institute of Children Oncology, Hematology and Transplantation (RICOHT) at the First St. Petersburg State Medical University. Clinical data about patients who underwent pharmacological therapy only have been presented by The National Research Center for Hematology ( $n=17)$; Russian Research Institute of Hematology and Transfusiology $(n=4)$, regional centers for hematology: Samara ( $n=2)$; Vologda $(n=1)$, Orel $(n=1)$, Penza $(n=3)$, Chelyabinsk $(n=1)$, Rostov $(n=1)$, Bryansk $(n=1)$, Murmansk $(n=1)$, Stavropol $(n=2)$, Volgograd $(n=2)$, Astrakhan $(n=1)$.

The main clinical characteristics of the patients are presented in Table 1. In total, 53 patients were enrolled into the study, at a median age of 42 (13 to 75) years at diagnosis, or 47 (1576) years since the T315I mutation was registered. Median time passed from starting therapy to revealing the mutation was $3.6(0.4-10.6)$ years. The time period from detection of the T315I marker to allo-HSCT was 236 (32 to 2189) days.

Table 1. Clinical characteristics of CML patients with Bcr/Abl T315I mutation

\begin{tabular}{|l|l|l|}
\hline Clinical and demographic parameters & Allo-HSCT & Drug therapy \\
\hline Number of patients & $\mathrm{N}=16$ & $\mathrm{~N}=37$ \\
\hline Number of transplants & $\mathrm{N}=18$ & \\
\hline Average age, years (range and median values) & $17-55$ & $17-77$ \\
& 34 & 49 \\
\hline Gender: & & \\
Males & 14 & 25 \\
Females & 2 & 12 \\
\hline Clinical stage at diagnosis: & & \\
Chronic phase & 6 & 29 \\
Acceleration phase & 10 & 8 \\
\hline $\begin{array}{l}\text { Stage at the time of T315I diagnosis: } \\
\text { Chronic phase }\end{array}$ & 4 & 23 \\
$\begin{array}{l}\text { Acceleration phase } \\
\text { Blast crisis }\end{array}$ & 10 & 11 \\
\hline Lines of therapy before the T315I diagnosis: & 2 & 3 \\
\hline 1 line & 2 & \\
$\geq 2$ lines & 3 & 5 \\
$\geq 3$ lines & 11 & 22 \\
\hline $\begin{array}{l}\text { Therapy after detecting the mutation: } \\
\text { Ponatinib } \\
\text { 1-2 generation TKI } \\
\text { Chemotherapy+TKI } \\
\text { Hydrea + Interferon }\end{array}$ & & 10 \\
\hline $\begin{array}{l}\text { Terms from primary diagnosis to T315I detection, } \\
\text { months (median values) }\end{array}$ & $8-115$ & 3 \\
\hline
\end{tabular}


Allo-HSCT and its outcomes. Four CML patients were in CP1 by the time of transplant. Seven patients were in CP2 phase (all the cases returned to $\mathrm{CP}$ after acceleration phase). The acceleration phase of CML was established in 5 cases, and 2 patients were in blast crisis before HSCT. HLA-identical siblings were HSC donors in 7 cases, whereas unrelated HLA-matched do nors have been used for eleven transplants. $69 \%$ patients $(n=11)$ received $>2$ TKI rounds before allo-HSCT.

A mean time from primary diagnosis to allo-HSCT was 39 (14-139) months; from the time of evolving mutation to allo-HSCT, 10 (2-38) months. EBMT score was as follows: 3-4 points, for 12 cases; 5 to 7 points, in 4 patients. Reduced-intensity conditioning regimens were used in 13 cases (81\%). Mean observation time for the surviving patients comprised 48 (8-79) months. Seven patients of 16 are now alive. By the moment of allo-HSCT, 2 patients were in CP1; 4, in CP2; 1 , in acceleration phase. All these patients are in deep molec-

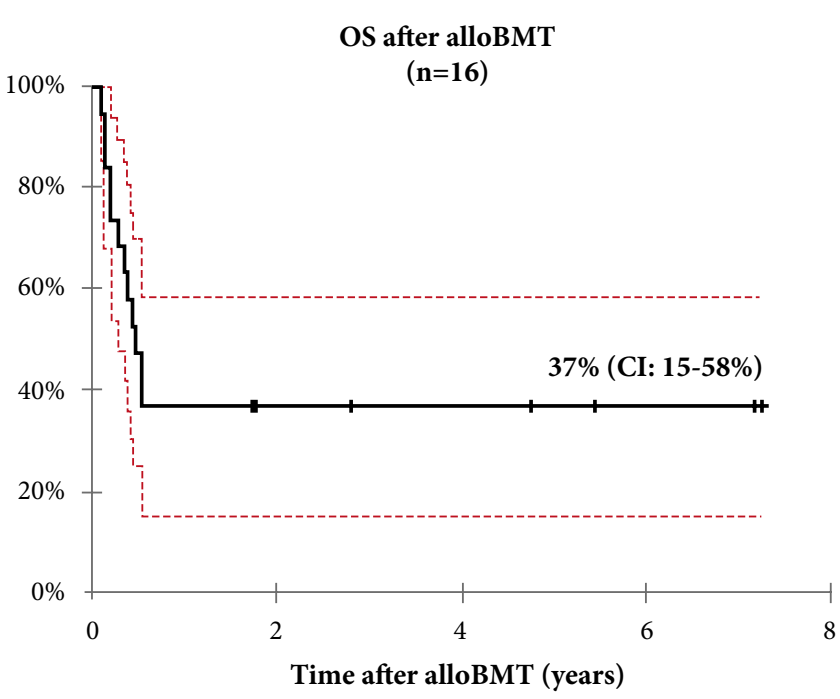

Figure 1. Overall survival of CML patients carrying T315I mutation (HSCT group).

Statistical evaluation. Methods of descriptive stastistics involved calculation of mediane values and minimal/maximal ranges. Survival analysis was performed according to Kaplan-Meier. Intergroup comparisons were carried out by means of a log-rank criterion. Regression analysis of survival was performed with a Cox model of proportional intensities. Multivariate regression analysis included the following factors and co-variates: age at the time of diagnosis, gender, disease phase at the beginning of therapy, stage of the disease at detection of the T315I mutation, subsequent treatment mode (with/without allo-HSCT); time until the mutation has been detected. OS evaluation was performed from the ular response, i.e., 3 patients, in $1^{\text {st }}$ response, and in 4 cases, the CMR was achieved after prophylactic TKI treatment. Causes of death in allo-HSCT group are as follows: progression of the disease in 3 cases; complications due to HSCT (primary non-engraftment; veno-occlusive disease of liver, sepsis). Overall survival (OS) for the transplanted patients proved to be $37 \%$ at 1 year, with a median observation time of 5 months (Fig. 1).

Drug therapy was performed in 37 cases $(21$ received TKI as monotherapy or in combination with other drugs, 16 were treated with hydroxyurea, $a$-interferon or chemotherapy). At present, median observation time of the surviving patients is 81 months (53-250). Of the patients treated with chemotherapy, 18 patients of 37 remain alive. Six patients are in $C P \geq 1$, nine patients are in hematological remission. Overall 5-year survival of the CML patients with T315I mutation constituted $42 \%$, and 8 -year survival was $31.6 \%$ (Fig. 2).

\section{OS after detection of the mutation}

T315I $(n=53)$

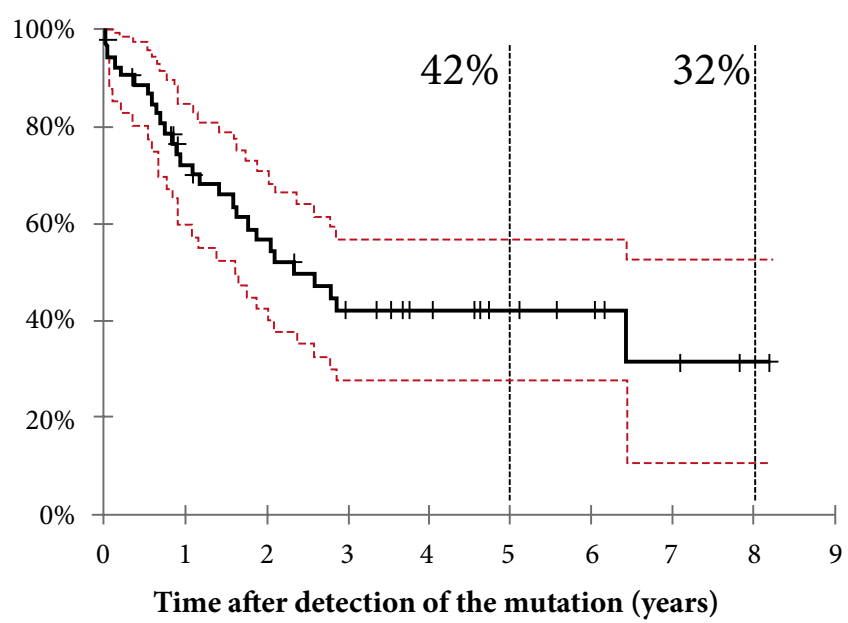

Figure 2. Overall survival of CML patients with T315I mutation (total study group)

date of mutation diagnosis (for entire group), and from the date of allo-HSCT (for the patients subjected to allo-HSCT) Analysis of progression-free and event-free survival was not performed. Lethality of all the patients could be interpreted as CML-associated (leukemia-caused death), or due to allo-HSCT complications (in HSCT patients). The differences were considered statistically significant by $p \leq 0.05$. Deep molecular response meant $B C R-A B L$ levels of $<0.01 \%$ by IS, including negative results of PCR with ABL copies more than 10000. 


\section{Results}

Comparative survival analysis for different disease phases showed that all the patients in blast crisis died during $1^{\text {st }}$ year after the mutation was been detected, with median survival of 1.3 months. Five-year and 8-year OS among patients in $\mathrm{CP} / \mathrm{AP}$ constituted $46.6 \%$ and $35 \%$, respectively (Fig. 3 ).

According to the results of comparative analysis for the groups of allo-HSCT and drug therapy, (all disease phases included), the five-year OS comprise $42 \%$ for the both groups $(\mathrm{p}=0.7)$. The overall survival median in HSCT group was 2 years, and in the drug therapy group, 2.6 years (Fig. 4). Similar analysis performed for the patients beyond blast crisis by the moment of mutation evolved has yielded similar results, i.e., 5-year OS was $47 \%$ in both groups (2.1 years for allo-HSCT group compared to 2.8 years among patients receiving drug therapy).

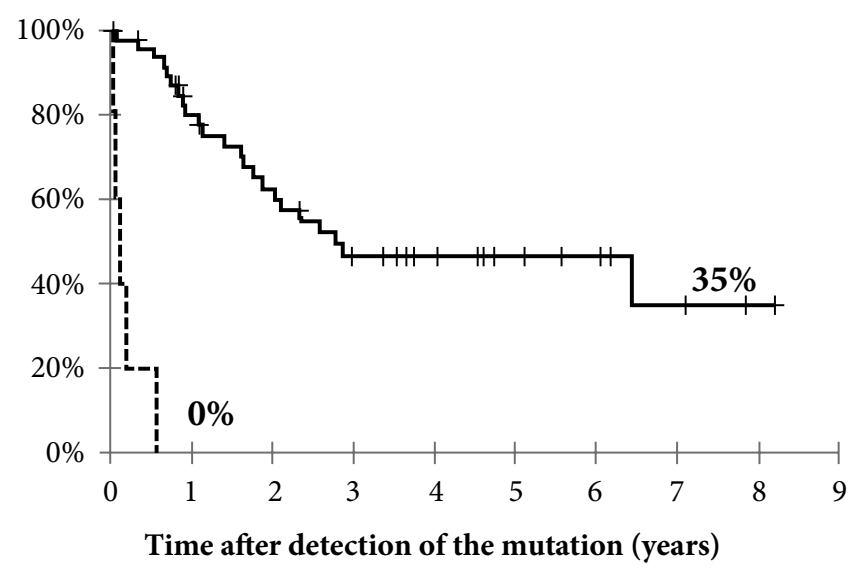

Figure 3. Differences in overall survival depend on disease phase at the time of $\mathrm{T} 315 \mathrm{I}$ mutation diagnosis: 1 , Blast crisis $(n=5)$; , Acceleration phase+chronic phase (48).

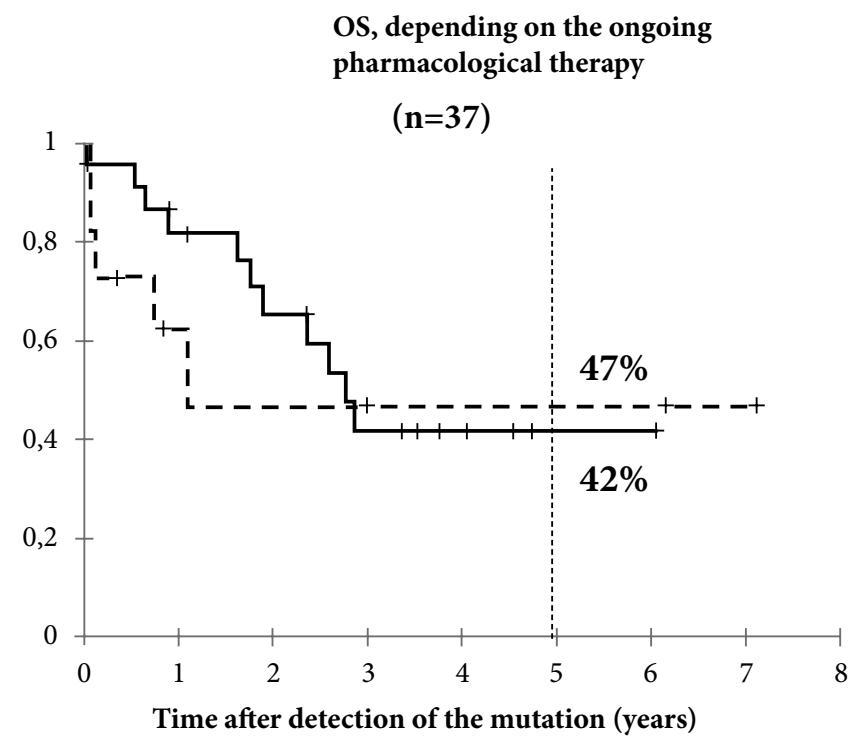

Our study has revealed an interesting fact, i.e., OS parameters in the group after detection of T315I mutations $(\mathrm{N}=37)$ did not sufficiently differ between the subgroups with drug therapy with or without TKI. For the patient group which was not treated with TKI $(\mathrm{N}=14)$, and for the group who received TKI (including those with combined therapy, $\mathrm{N}=23$ ), 5-year OS comprised, respectively, $46.7 \%$ and $42.1 \%$ ( $\mathrm{p}=0.53$ ). The median of overall survival after TKI-free therapy was 1 year, compared to 2.8 years in TKI-treated group (Fig. 5).

Multivariate analysis of multiple effects upon OS has shown that the only independent significant factor was the disease phase, i.e., blast crisis by the moment of mutation detection. A total of five patients were at the $\mathrm{BC}$ phase by detection of the mutation. Two of them underwent HSCT, all the patients deceased (Table 2).

OS depending on the therapy

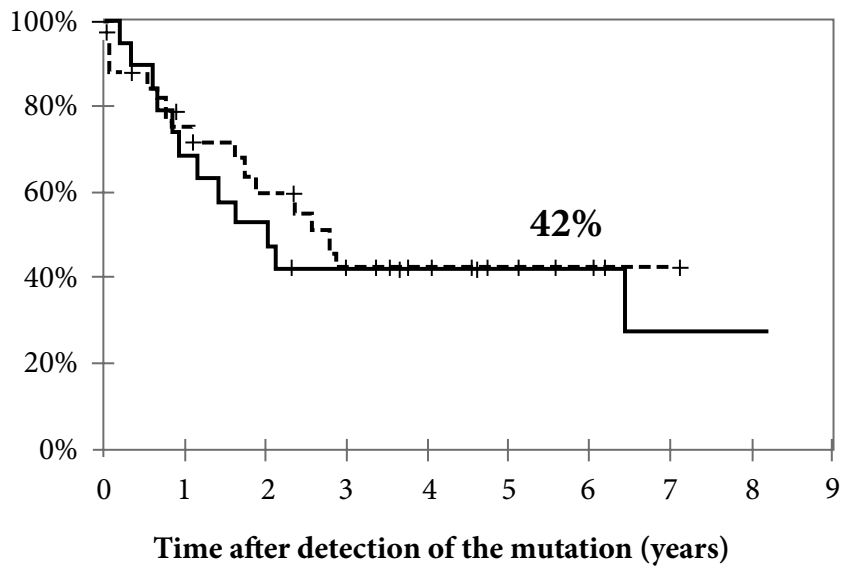

Figure 4. Comparative analysis of overall survival for groups 1 (allo-HSCT, n=16), and 2 (drug therapy alone, $n=37)$.

Figure 5. Comparative survival analysis dependent on the type of drug therapy after the T315I mutation detection: 1, TKI-free $(n=14) ; 2$, TKI applied $(n=23)$. 
Table 2. Multifactorial analysis: effects of certain factors on the overall survival at the time of T315I detection

\begin{tabular}{|l|l|l|l|}
\hline \multirow{2}{*}{ Factors and covariates } & \multicolumn{2}{l}{ Cox regression analysis of survival } \\
\cline { 2 - 4 } & Beta & $\mathrm{p}$ & Risk ratio \\
\hline Gender & $-0,03888$ & 0,938959 & 0,96186 \\
\hline Age & $-0,00026$ & 0,988954 & 0,99974 \\
\hline Phase of disease upon starting therapy & $-0,03291$ & 0,940797 & 0,96763 \\
\hline Allo-HSCT performed & 0,130761 & 0,777792 & 1,13969 \\
\hline Terms from detection to starting the therapy & $-7 \mathrm{E}-06$ & 0,979336 & 0,99999 \\
\hline Blast crisis by the time of studying mutational status & 3,682117 & 0,000004 & 39,73043 \\
\hline
\end{tabular}

\section{Discussion}

According to recommendations of the European LeukemiaNet (ELN, 2011), testing for BCR-ABL mutations by means of direct sequencing is obligatory in case of treatment failure. This analysis aims to deciffer nucleotide sequence of the kinase domain in cDNA product. The method includes RNA extraction from patients' blood, reverse transcription getting complementary DNA (cDNA), amplification of the $B C R / A B L$ kinase gene segment, followed by its sequencing [2]. This method allows to determine all the spectrum of the kinase domain mutations with a sensitivity of $15-20 \%$.

To detect a transcript bearing T315I mutation, as well for quantitative evaluation of the mutant/wild-type clone ratio, the AC PCR is used. This approach is highly sensitive, thus allowing to find minor subclones which are undetectable by direct desequencing. AC PCR enables dynamic studies of the mutant clone, e.g., for evaluation or prediction of the treatment efficiency [41]. A minimal presence of the $B C R-A B L^{T 3151}$ clone ( $\geq 10-5$ against GUS) could be an unfavorable sign for achievement of major molecular response in imatyinib-resistant patients receiving TKI2 (nilotinib or dasatinib) [20].

Another sensitive technique for the diagnostics of mutations is a novel method of deep sequencing (ultra-deep sequencing, UDS), which allows to detect mutant subclones at a range of 1 to $15 \%$ in the cell populations which may be of clinical significance for resistance diagnostics but cannot be detected by means of direct sequencing [36].

Despite ELN recommendations on direct sequencing method as an optimal approach to searching $B C R / A B L$ mutations, more precise techniques seem to be available in the nearest future, due to discovery and clinical studies of novel, highly efficient drugs. Allo-HSCT is known to be an effective mode to treat T315I-positive CML.

Therefore, let us briefly discuss the prospectives of drug therapy and future therapeutic approaches to this category of the patients. E.g., ponatinib (AP24534, Iclusig ${ }^{\text {tw1 }}$ ) provided a new approach to therapy of CML positive for $B C R-A B L^{\mathrm{T} 315 \mathrm{I}}$. This TKI inhibits several kinase targets, being active in cases of
T315I mutation and multiple mutations in the $B C R-A B L$ kinase domain. This compound does not form hydrogen links with T315 in the kinase domain of $B C R-A B L$, due to incorporation of vinyl and ethyl bonds into the inhibitor nucleotides, thus it does not prevent its spatial binding to the protein [29].

The data on 2-year observations concerning efficiency and safety of ponatinib at a dose of $45 \mathrm{mg} /$ day were published in 2013 as a $2^{\text {nd }}$ phase of PACE clinical study. The study included 449 patients. Among them 227 patients with CP CML were under study being resistant/intolerable to previous therapy with TKI, including patients with T315I mutation. In this subgroup of pre-treated patients with failure of several lines of therapy, $58 \%$ patients received $>3 \mathrm{TKI}$ at preceding treatment rounds. Mean total terms of the previous comprised 6 (0.3 to 28) years. According to the data from 2-year observation, $46 \%$ of the patients still remained in the PACE study, of them $60 \%$ CML patients were in chronic phase. The rates of PFS and OS in the CP patients made $80 \%$ (a median of 27 months), and 94\% (median, 12 mo); PFS and OS in patients with blast crisis comprised 18\% (a median of $4 \mathrm{mo}$ ), and 30\% (a median of 7 mo.). Among CML group, most patients with CP retained the response until 12 months, i.e., $91 \%, 91 \%$ and $75 \%$ of the patients presented with, respectively, MCyR, complete cytogenetic response, or MMR [16]. Moreover, the studies report on increased cumulative frequency of serious arterial thrombotic complications associated with ponatinib treatment $[5,27]$.

Omacetaxin/Homoharringtonin (Synribo ${ }^{\circ}$ ) was another drug approved by FDA (USA Food and Drug Administration) for CML cases resistant to $\geq 2$ TKIs. According to the II phase clinical trials in patients with T315I mutation and failure of TKI therapy, 48 of 62 patients in CP (77\%) have achieved complete hematological response, whereas 10 (16\%) achieved complete cytogenetic response[6].

Among experimental compounds acceptable for T315I-positive CML therapy, one may suggest PF-114 which now undergoes $1^{\text {st }}$ phase of clinical trials. The drug is a TKI which is targeted for BCR-ABL. Efficiency of this molecule is in vitro shown using resistant mutant cell lines (Y253F, E255K, T315I, F317L). A range of suppressible tyrosine kinases (27 
species with PF-114, as compared to 80 with ponatinib) reflects its higher selectivity thus reducing probability of potential in vivo adverse effects [21]. The most discussed and prospective ABL001 compound which is also under Phase 1 of clilnical trials. Early proofs are presented for its clinical efficiency towards mutations causing TKI resistance (V299L, F317L, Y253H). Allosteric BCR-ABL1 inhibition represents another promising therapeutic approach to therapy of CML patients [31].

\section{Conclusion}

Targeted therapy in CML sufficiently increases life expectance of the patients, causing marked malignancy reduction to undetectable levels of molecular response. So far, however, the issues of resistance remain unresolved despite TKI2 introduction. Development of clones bearing T315I mutation in resistant CML changes prognosis for the given cohort of patients since it makes impossible a target effect upon leukemia cells. This problem required improvement of novel molecular diagnostics, as well as development of new molecules efficient in $B C R-A B L^{\mathrm{T} 315 \mathrm{I}}$-positive patients.

Currently, T315I positivity is an absolute indication for allogeneic bone marrow transplantation. Along with HLAmatched related or unrelated donors, related haploidentical donors may be also considered. Achievement of deep molecular remission is an evident advantage of allo-HSCT in these cases.

Our results suggest that pharmacological treatment is acceptable, if T315I mutation is revealed at chronic phase of the disease. However, there is no evidence that imatinib or TKI2 continuation will lead to the mutant clone selection, increased $B C R-A B L^{\mathrm{T} 315 \mathrm{I}}$ expression and further progression of the disease. Treatment of CML blast crisis seems to be ineffective, using both pharmacological therapy, and allo-HSCT approaches. Hence, therapeutic choice after the T315I detection should be based on risk factors, with CML stage being of major importance.

We need long-range observations of large patient cohorts using highly sensitive T315I detection techniques, in order to study its biological characteristics (role for CML progression, proliferative activity etc.) and to develop optimal therapeutic strategy.

Introduction of novel effective approaches to clinical practice will allow to reduce the number of patients with TKI resistance and to improve general therapeutic effect.

\section{Conflicts of interest}

No conflict of interest is declared.

\section{Funding sources}

The study did not have any sponsor support.

\section{References}

1. Barrett AJ, Ito S. The role of stem cell transplantation for chronic myelogenous leukemia in the $21^{\text {st }}$ century. Blood. 2015;125(21):3230-3235.

2. Branford S, Rudzki Z, Walsh S, Grigg A, Arthur C, Taylor K, Herrmann R, Lynch KP, Hughes TP. High frequency of point mutations clustered within the adenosine triphosphate-binding region of $\mathrm{BCR} / \mathrm{ABL}$ in patients with chronic myeloid leukemia or $\mathrm{Ph}$ positive acute lymphoblastic leukemia who develop imatinib (STI571) resistance. Blood. $2002 ; 99(9): 3472-3475$.

3. Corbin AS, Buchdunger E, Pascal F, Druker BJ. Analysis of the structural basis of specificity of inhibition of the Abl kinase by STI571. J Biol Chem 2002; 277:32214-32219.

4. Cornelison AM, Welch MA, Koller C, Jabbour E. Dasatinib combined with Interferon-alfa induces a complete cytogenetic response and major molecular response in a patient with chronic myelogenous leukemia harboring the T315I BCR-ABL1 mutation. Clin Lymphoma Myeloma Leuk. 2011 Jun;11 Suppl 1:S111-3.

5. Cortes JE, Kim DW, Pinilla-Ibarz J, le Coutre P, Paquette R, Chuah C, Nicolini FE, Apperley JF, Khoury HJ, Talpaz M, DiPersio J, DeAngelo DJ, Abruzzese E, Rea D, Baccarani M, Müller MC, Gambacorti-Passerini C, Wong S, Lustgarten S, Rivera VM, Clackson T, Turner CD, Haluska FG, Guilhot F, Deininger MW, Hochhaus A, Hughes T, Goldman JM, Shah NP, Kantarjian H. A phase 2 trial of ponatinib in Philadelphia chromosome-positive leukemias. New Engl J Med. 2013;369:1783-1796.

6. Cortes, J.H. Lipton, D. Rea, R. Digumarti, C. Chuah, N. Nanda et al. Phase 2 study of subcutaneous omacetaxine mepesuccinate after TKI failure in patients with chronic-phase CML with T315I mutation. Blood 2012;120: 2573-2580.

7. Cortes JE, Kim D-W, Pinilla-Ibarz J, D le Coutre P, Paquette R, Chuah C, Nicolini FE, Apperley JF, Khoury HJ, Talpaz M, DiPersio JF, DeAngelo DJ, Abruzzese E, Rea D, Baccarani M, Müller MC, Passerini CG, Lustgarten S, Rivera VM, Clackson T, Turner CD, Haluska FG, Guilhot F, Deininger MW, Hochhaus A, Hughes TP, Goldman JM, Shah NP,Kantarjian HM. Ponatinib in patients (pts) with chronic myeloid leukemia (CML) and Philadelphia chromosome-positive acute lymphoblastic leukemia ( $\mathrm{Ph}+\mathrm{ALL})$ resistant or intolerant to dasatinib or nilotinib, or with the T315I BCR-ABL mutation: 2-year follow-up of the PACE trial. Blood. 2013; 122:650.

8. de Lavallade H, Khorashad JS, Davis HP, Milojkovic D, Kaeda, JS, Goldman JM, et al. Interferon-alpha or homoharringtonine as salvage treatment for chronic myeloid leukemia patients who acquire the T315I BCR-ABL mutation. Blood. 2007;110: 2779-2780.

9. Goldman J, Melo J. Chronic myeloid leukemia advances in biology and new approaches to treatment. N Engl J Med. 2003; 349: 1451-1464.

10. Gorre ME, Mohammed M, Ellwood K, Hsu N, Paquette R, Rao PN, Sawyers CL. Clinical resistance to STI-571 cancer 
therapy caused by BCR-ABL gene mutation or amplification. Science. 2001; 293:876-880.

11. Hochhaus A, Kreil S, Corbin AS, La Rosée P, Müller MC, Lahaye T, Hanfstein B, Schoch C, Cross NC, Berger U, Gschaidmeier H, Druker BJ, Hehlmann R. Molecular and chromosomal mechanisms of resistance to imatinib (STI571) therapy. Leukemia. 2002; 16, 2190-2196.

12. Ilander M, Koskenvesa P, Hernesniemi S, Lion T, Porkka K, Mustjoki S. Induction of sustained deep molecular response in a patient with chronic-phase T315I-mutated chronic myeloid leukemia with interferon- $\alpha$ monotherapy. Leuk Lymphoma. 2014; 55(4):934-937.

13. Itonaga $H$, Tsushima $H$, Hata $T$, Matsuo $E$, Imanishi D, Imaizumi Y, Kawaguchi Y, Fukushima T, Doi Y, Mori S, Kamihira S, Tomonaga M, Miyazaki Y. Successful treatment of a chronic-phase T-315I-mutated chronic myelogenous leukemia patient with a combination of imatinib and interferon-alfa. Int J Hematol. 2012; 95:209-213.

14. Jabbour E, Kantarjian H, Jones D, Talpaz M, Bekele N, O'Brien S, Zhou X, Luthra R, Garcia-Manero G, Giles F, Rios $\mathrm{MB}$, Verstovsek S, Cortes J. Frequency and clinical significance of BCR-ABL mutations in patients with chronic myeloid leukemia treated with imatinib mesylate. Leukemia (2006) 20, 1767-1773.

15. Kantarjian H, Sawyers C, Hochhaus A, Guilhot F, Schiffer C, Gambacorti-Passerini C, Niederwieser D, Resta D, Capdeville R, Zoellner U, Talpaz M, Druker B, Goldman J, O’Brien SG, Russell N, Fischer T, Ottmann O, Cony-Makhoul P, Facon T, Stone R, Miller C, Tallman M, Brown R, Schuster M, Loughran T, Gratwohl A, Mandelli F, Saglio G, Lazzarino M, Russo D, Baccarani M, Morra E. Hematologic and cytogenetic responses to imatinib mesylate in chronic myelogenous leukemia. N.Engl. J. Med. 2002; 346: 645-652.

16. Kantarjian HM, Cortes JE, O'Brien S, Giles F, Garcia-Manero G, Faderl S, Thomas D, Jeha S, Rios MB, Letvak L, Bochinski K, Arlinghaus R, Talpaz M. Imatinib mesylate therapy in newly diagnosed patients with Philadelphia chromosome-positive chronic myelogeno us leukemia: high incidence of early complete and major cytogenetic responses. Blood 2003; 101: 97-100.

17. Kantarjian HM, Talpaz M, Giles F, O’Brien S, Cortes J. New Insights into the Pathophysiology of Chronic Myeloid Leukemia and Imatinib Resistance, Mechanisms of resistance to imatinib in chronic myeloid leukaemia Ann Intern Med. 2006;145(12):913-923.

18. Khorashad JS, de Lavallade H, Apperley JF, Milojkovic D, Reid AG, Bua M, Szydlo R, Olavarria E, Kaeda J, Goldman JM, Marin D. Finding of kinase domain mutations in patients with chronic phase chronic myeloid leukemia responding to imatinib may identify those at high risk of disease progression. J Clin Oncol. 2008; 26 (29) 4806-13.

19. Kutsev S.I., Mordanov S.V. Amplification of the BCR-ABL gene in patients with chronic myeloid leukemia, refractory to imatinib. Oncohematology 2009; 3: 23-26.(In Russian).
20. Lange T, Ernst T, Gruber FX, Maier J, Cross M, Müller M, Niederwieser D, Hochhaus A, Pfirrmann M. The quantitative level of T315I mutated BCR-ABL predicts for major molecular response to second-line nilotinib or dasatinib treatment in patients with chronic myeloid leukemia. Haematologica. 2013 May; 98(5): 714-717.

21. Mian AA, Rafiei A, Metodieva A, Haberbosch I, Zeifman A, Titov I, Stroylov V, Stroganov O, Novikov F, Chilov G, Ottmann OG, Ruthardt M. PF-114, a novel selective panBCR/ABL inhibitor targets the T315I and suppress models of advanced Ph+ ALL. Blood. 2013; 122: 213907

22. Nicolini FE, Basak GW, Kim D-W, Olavarria E, Pinilla-Ibarz J, Apperley JF, Hughes TP, Niederwieser D, Mauro MJ, Chuah C, Hochhaus A, Martinelli G, DerSarkissian M, Kageleiry A, Yang M, Huang H, McGarry LJ, Kantarjian $\mathrm{HM}$, Cortes JE. The impact of ponatinib versus allogeneic stem cell transplant (SCT) on outcomes in patients with chronic myeloid leukemia (CML) or Philadelphia chromosome-positive acute lymphoblastic leukemia ( $\mathrm{Ph}+\mathrm{ALL})$ with the T315I mutation, Abstract 480,57th Annual Meeting ASH, 2015

23. Nicolini FE, Basak GW, Soverini S, Martinelli G, Mauro MJ, Müller MC, Hochhaus A, Chuah C, Dufva IH, Rege-Cambrin G, Saglio G, Michallet M, Labussière H, Morisset S, Hayette S, Etienne G, Olavarria E, Zhou W, Peter S, Apperley JF, Cortes J. Allogeneic stem cell transplantation for patients harboring T315I BCR-ABL mutated leukemias. Blood. 2011; 118 (20): 5697-5700.

24. Nicolini FE, Corm S, Lê QH, Sorel N, Hayette S, Bories D, Leguay T, Roy L, Giraudier S, Tulliez M, Facon T, Mahon FX, Cayuela JM, Rousselot P, Michallet M, Preudhomme C, Guilhot F, Roche-Lestienne C. Mutation status of 89 imatinib mesylate resistant chronic myelogenous leukemia patients and clinical outcome. A retrospective analysis from the french intergroup of CML (Fi(phi)-LMC group). 2006, Leukemia 20:1061-1066.

25. Nicolini FE, Corm S, Lê QH, Sorel N, Hayette S, Bories D, Leguay T, Roy L, Giraudier S, Tulliez M, Facon T, Mahon FX, Cayuela JM, Rousselot P, Michallet M, Preudhomme C, Guilhot F, Roche-Lestienne C. Mutation status and clinical outcome of 89 imatinib mesylate-resistant chronic myelogenous leukemia patients: a retrospective analysis from the French intergroup of CML (Fi(phi)-LMC GROUP). Leukemia. 2006;20(6):1061-1066.

26. Nicolini FE, Mauro MJ, Martinelli G, Kim DW, Soverini S, Müller MC, Hochhaus A, Cortes J, Chuah C, Dufva IH, Apperley JF, Yagasaki F, Pearson JD, Peter S, Sanz Rodriguez C, Preudhomme C, Giles F, Goldman JM, Zhou W. Epidemiologic study on survival of chronic myeloid leukemia and $\mathrm{Ph}(+)$ acute lymphoblastic leukemia patients with BCRABL T315I mutation. Blood 2009; 114: 5271 - 5278.

27. O’Brien S, Radich JP, Abboud CN, Akhtari M, Altman JK, Berman E, Curtin P, DeAngelo DJ, Deininger M, Devine S, Fathi AT, Gotlib J, Jagasia M, Kropf P, Moore JO, Pallera A, Reddy VV, Shah NP, Smith BD, Snyder DS, Wetzler M, Gregory K, Sundar H. Chronic myelogenous leukemia, version 1.2015. J Natl Compr Canc Netw. 2014;12(11):1590-1610. 
28. O’Brien SG, Guilhot F, Larson RA, Gathmann I, Baccarani M, Cervantes F, Cornelissen JJ, Fischer T, Hochhaus A, Hughes T, Lechner K, Nielsen JL, Rousselot P, Reiffers J, Saglio G, Shepherd J, Simonsson B, Gratwohl A, Goldman JM, Kantarjian H, Taylor K, Verhoef G, Bolton AE, Capdeville R, Druker BJ. Imatinib compared with interferon and low-dose cytarabine for newly diagnosed chronic-phase chronic myeloid leukemia. N Engl J Med. 2003; 348: 9941004 .

29. O’Hare T, Shakespeare WC, Zhu X, Eide CA, Rivera VM, Wang F, Adrian LT, Zhou T, Huang WS, Xu Q, Metcalf CA 3rd, Tyner JW, Loriaux MM, Corbin AS, Wardwell S, Ning Y, Keats JA, Wang Y, Sundaramoorthi R, Thomas M, Zhou D, Snodgrass J, Commodore L, Sawyer TK, Dalgarno DC, Deininger MW, Druker BJ, Clackson T. AP24534, a PanBCR-ABL inhibitor for chronic myeloid leukemia, potently inhibits the T315I mutant and overcomes mutation-based resistance. Cancer Cell. 2009; 16(5): 401-412.

30. O’Hare T, Walters DK, Stoffregen EP, Jia T, Manley PW, Mestan J, Cowan-Jacob SW, Lee FY, Heinrich MC, Deininger MW, Druker BJ. In vitro activity of Bcr-Abl inhibitors AMN107 and BMS- 354825 against clinically relevant imatinib-resistant Abl kinase domain mutants. Cancer Res. 2005; 65: 4500-4505.

31. Ottmann OG, Alimena G, DeAngelo DJ, Goh Y-T, Heinrich MC, Hochhaus A, Hughes TP, Mahon F-X, Mauro MJ, Minami H, Nguyen MH, Rea D, Steegmann JL, Chatterjee A, Iyer V, Martinez N, Vanasse GJ, Dong-Wook K. ABL001, a potent, allosteric inhibitor of BCR-ABL, exhibits safety and promising single- agent activity in a phase I study of patients with CML with failure of prior TKI therapy. Abstract 138, 57 $7^{\text {th }}$ Annual Meeting ASH, 2015.

32. Peggs K, Mackinnon S. Imatinib mesylate - the new gold standard for treatment of chronic myeloid leukemia. N Engl J Med. 2003; 348: 1048-1050.

33. Sattler M, Verma S, Shrikhande G, Byrne CH, Pride YB, Winkler T, Greenfield EA, Salgia R, Griffin JD. The BCR/ $\mathrm{ABL}$ tyrosine kinase induces production of reactive oxygen species in hematopoietic cells. J Biol Chem. 2000; 275(32): 24273-24278.

34. Shah NP, Nicoll JM, Nagar B, Gorre ME, Paquette RL, Kuriyan J, Sawyers CL. Multiple BCR-ABL kinase domain mutations confer polyclonal resistance to the tyrosine kinase inhibitor imatinib (STI571) in chronic phase and blast crisis chronic myeloid leukemia. Cancer Cell 2002; 2: 117-125.

35. Soverini S, Colarossi S, Gnani A, Rosti G, Castagnetti F, Poerio A, Iacobucci I, Amabile M, Abruzzese E, Orlandi E, Radaelli F, Ciccone F, Tiribelli M, di Lorenzo R, Caracciolo C, Izzo B, Pane F, Saglio G, Baccarani M, Martinelli G. Contribution of $\mathrm{ABL}$ kinase domain mutations to imatinib resistance in different subsets of Philadelphia-positive patients: by the GIMEMA Working Party on Chronic Myeloid Leukemia. Clin Cancer Res 2006; 12:7374-7379.

36. Soverini S, De Benedittis C, Machova Polakova K, Brouckova A, Horner D, Iacono M, Castagnetti F, Gugliotta G, Palandri F, Papayannidis C, Iacobucci I, Venturi C, Bochicchio MT, Klamova H, Cattina F, Russo D, Bresciani
P, Binotto G, Giannini B, Kohlmann A, Haferlach T, Roller A, Rosti G, Cavo M, Baccarani M, Martinelli G. Unraveling the complexity of tyrosine kinase inhibitor-resistant populations by ultra-deep sequencing of the BCR-ABL kinase domain. Blood, 2013; 122(9): 1634-1648.

37. Soverini S, Martinelli G, Rosti G, Bassi S, Amabile M, Poerio A, Giannini B, Trabacchi E, Castagnetti F, Testoni N, Luatti S, de Vivo A, Cilloni D, Izzo B, Fava M, Abruzzese E, Alberti D, Pane F, Saglio G, Baccarani M. ABL mutations in late chronic phase chronic myeloid leukemia patients with up-front cytogenetic resistance to imatinib are associated with a greater likelihood of progression to blast crisis and shorter survival: a study by the GIMEMA Working Party on Chronic Myeloid Leukemia. J. Clin. Oncol. 2005; 23: 41004109.

38. Turkina A.G., Khoroshko N.D., Druzhkova G.A., Zingerman B.V., Zakharova E.S., Chelysheva E. Yu., Vinogradova O. Yu., Domracheva E.V., Zakharova A.V., Kovaleva L.G., Kolosheinova T.I., Kolosova L. Yu., Zkuravleva V.S., Tikhonova L. Yu. Therapeutic efficacy of Imatinib Mesilate (Glivec) in chronic phase of myeloid leukemia.Ter Arkhiv 2003; 75(8): 62-67. (In Russian).

39. Velev N, Cortes J, Champlin R, Jones D, Rondon G, Giralt S, Borthakur G, Kantarjian HM, De Lima M. Stem cell transplantation for patients with chronic myeloid leukemia resistant to tyrosine kinase inhibitors with BCR-ABL kinase domain mutation T315I. Cancer. 2010;116:3631-3637.

40. Wongboonma W, Thongnoppakhun W, Auewarakul CU. A single-tube allele specific-polymerase chain reaction to detect T315I resistant mutation in chronic myeloid leukemia patients. J Hematol Oncol. 2011 Feb 8;4:7. doi: 10.1186/17568722-4-7.

41. Xu LP, Xu ZL, Zhang XH, Chen H, Chen YH, Han W, Chen Y, Wang FR, Wang JZ, Wang Y, Yan CH, Mo XD, Liu KY, Huang XJ. Allogeneic stem cell transplantation for patients with T315I BCR-ABL mutated chronic myeloid leukemia. Biol Blood Marrow Transplant. 2016;22(6):10801086.

42. Zeidner JF, Zahurak M, Rosner GL, Gocke CD, Jones RJ, Smith D. The evolution of treatment strategies for patients with chronic myeloid leukemia relapsing after allogeneic bone marrow transplantation: Can tyrosine kinase inhibitors replace donor lymphocyte infusions. Leuk Lymphoma. 2015; 56(1): 128-134. 


\title{
Клинические характеристики и исходы лечения у пациентов хроническим миелоидным лейкозом с мутацией Т315।
}

\author{
Юлия Ю. Власова ${ }^{1}$, Олег А. Шухов ${ }^{2}$, Елена В. Морозова ${ }^{1}$, Мария В. Барабанщикова ${ }^{1}$ Татьяна Л. Гиндина ${ }^{1}$, \\ Ильдар М. Бархатов ${ }^{1}$, Ирина С. Мартынкевич ${ }^{3}$, Василий А. Шуваев ${ }^{3}$, Анна Г. Туркина ${ }^{2}$, Борис В. Афанасьев ${ }^{1}$ \\ ${ }^{1}$ НИИ Детской Онкологии Гематологии и Трансплантологии им. Р. М. Горбачевой \\ Первый Санкт-Петербургский Государственный Медицинский Университет им. акад. И. П. Павлова, Санкт-Петербург \\ ${ }^{2}$ «Национальный медицинский исследовательский центр гематологии» Минздрава России, Москва, Россия \\ ${ }^{3}$ «оссийский НИИ Гематологии и Трансфузиологии», ФМБА, Санкт-Петербург
}

\section{Резюме}

Современное лечение хронического миелоидного лейкоза (ХМЛ) основано на применении ингибиторов тирозинкиназ (ИТК). Несмотря на высокую эффективность ИТК, некоторые пациенты в ХФ и значительно большее количество пациентов в ФА и БК оказываются к нему резистентными. Наиболее важный из обсуждаемых механизмов резистентности к ИТК - возникновение точечных мутаций в киназном домене ABL-тирозинкиназы. На сегодня T315I считается единственной мутацией, вызывающей резистентность лейкозных клеток ко всем известным ИТК I и II поколения, кроме понатиниба. Целью нашей работы была оценка результатов различных методов лечения у пациентов с мутацией Т315I ХМЛ.

\section{МАТЕРИАЛЫ И МЕТОДЫ}

Приведены результаты ретроспективного анализа $53 B C R-A B L^{\mathrm{T} 315 \mathrm{I}}$-позитивных пациентов. 18 аллогенных трансплантаций костного мозга (аллоТГСК) выполнены 16 пациентам, фармакологическую терапию получили 37 пациентов (21 получали ИТК в качестве монотерапии или в комбинации с другими препаратами, 16 получали гидроксикарбамид, $а$-интерферон или химиотерапию). К моменту алло-ТГСК 4 пациента находились в хронической фазе 1 (ХФ1); 7 - в ХФ 2; 5 - в фазе акселерации (ФА); 2 - в бластном кризе (БК). Медиана возраста на момент выявления мутации составляла 47 лет (15-76), или 38 лет в группе алло-ТГСК. В группе алло-ТГСК в 7 случаях донорами были HLA-идентичные сиблинги, в 11 - неродственные доноры, 11 пациентов (69\%) получили более 2 линий лечения ИТК до проведения алло-ТГСК. Количество баллов по шкале ЕВМТ: 3-4 балла - 12 пациентов; 5-7 баллов - у 4 пациентов. Режим кондиционирования в 13 случаях (81\%) был со сниженной интенсивностью доз. Медиана времени от выявления мутации до алло-ТГСК составила 10 месяцев (2-38). Анализ выживаемости проводили с использованием метода Каплан-Майера; сравнение в группах осуществляли с применением лог-рангового критерия. Регресси- онный анализ выживаемости выполнен с применением модели пропорциональных интенсивностей Кокса. Многофакторный регрессионный анализ включал следующие факторы и ковариаты: возраст на дату диагноза, пол, фаза на начало терапии, фаза на дату выявления мутации, терапия после выявления мутации (без алло-ТГСК и с алло-ТГСК), время до выявления мутации от начала терапии. Результаты исследования: медиана времени наблюдения после выявления мутации Т315I составляла 21 месяц (1-100). 5-летняя общая выживаемость (ОВ) была $42 \%$. По данным многофакторного анализа, только фаза ХМЛ на время обнаружения мутации значительно влияла на ОВ всей группы. Всего в фазе БК на момент выявления мутации были 5 человек, 2-м из них была выполнена алло-ТГСК. Все больные умерли в течение 1-го года после индикации Т315I с медианой выживаемости 1.3 месяца. 5-летняя ОВ в группе фармакологической терапии $(\mathrm{n}=37)$ была $42 \%$ с медианой выживаемости 2.8 года. 3-летняя ОВ в группе алло-ТГСК $(\mathrm{n}=16)$ - 37\%, медиана выживаемости составила 5 месяцев. У всех пациентов после алло-ТГСК получен глубокий молекулярный ответ. Не обнаружено достоверных различий в группах фармакологической терапии без ИТК $(\mathrm{N}=11)$; и включая ИТК $(\mathrm{N}=23)$ по показателям 5-летней $\mathrm{OB}$ ( $42 \%$ и $47 \%$ соответственно, $\mathrm{p}=0,53$ ).

\section{ЗАКЛЮЧЕНИЕ}

Появление клона с мутацией T315I у больных ХМЛ с резистентностью изменяет прогноз для данной категории пациентов, особенно в продвинутых фазах. Выявление данной мутации является основанием для переключения на понатиниб или другие экспериментальные препараты. Алло-ТГСК остается потенциальной терапевтической опцией, однако необходимо учитывать трансплантационные риски.

\section{Ключевые слова}

Хронический миелоидный лейкоз, мутация Т315I, аллогенная трансплантация гемопоэтических стволовых клеток, лекарственная резистентность. 